\title{
Training on Economic Empowerment for Fishermen Community in Ambulu Village, Losari Sub-District, Cirebon Regency, West Java, Indonesia
}

\author{
Sukono $^{1 *}$, Riaman $^{2}$, Endang Soeryana Hasbullah ${ }^{3}$ \\ ${ }^{1,2,3}$ Department of Mathematics, Faculty of Mathematics and Natural Sciences, \\ Padjadjaran University Indonesia \\ Authorsemail: sukono@unpad.ac.id; riaman@unpad.ac.id; endang.soeryana@unpad.ac.id
}

\begin{abstract}
The welfare of fishermen in Indonesia is still very low and many of them have not been able to meet their family's daily needs. This is caused by various factors that affect their economic condition. This paper aims to conduct economic empowerment training for fisheries communities in Ambulu Village, Losari District, Cirebon Regency, West Java, Indonesia. In this study, 115 respondents Ambulu village fishermen are included in the study. The reviewed factors include social factors, work system factors, and economic factors themselves in meet the needs of fishermen's family. As much as $79.13 \%$ of respondents were able to meet their daily needs, while $20.87 \%$ were unable to meet their daily needs. This shows that other efforts are needed from fishermen to fulfil their daily needs in order to improve their welfare.
\end{abstract}

Keywords: fishermen, economy, fisherman welfare needs

\section{Introduction}

Fishermen have a very important role in the fisheries and marine sectors, as this sector has the potential to become one of the keys to economic growth in Indonesia. However, the fishermen also have a high risk of losing their lives (Firdaus \& Witomo, 2014). The risk of losing their lives is not directly proportional to the low level of welfare of fishermen in Indonesia. Anwar and Wahyuni (2019) study that the majority of fishing communities in Indonesia live below the poverty line, even contributing around $25 \%$ of the national poverty rate. This is of course very concerning for fishermen, because they do not get the life they should be in accordance with the amount of effort and risk in their work. Therefore, it takes efforts from various parties to improve the welfare of fishermen in Indonesia.

Indicators of the level of fishermen's welfare are most easily measured by whether or not the daily needs of fishermen's families are met (Yunita et al., 2018), as many fishing families have difficulty fulfilling their daily needs. In addition, Prihandoko et al. (2012) stated that when talking about fishermen's welfare, it cannot be separated from the characteristics of their social and economic conditions. Other Factors that not less important are factors that affect the fishermen catch which will also affect the fishermen's income to meet daily needs (Yunita et al., 2018). After knowing the factors that affect the fishermen welfare and indicators of their welfare, steps can be formulated to develop the economy of fisheries communities in Indonesia.

Data collection and analysis in social and economic terms is very important to formulate steps to improve the welfare of fisheries communities in Indonesia. Therefore, this research will discuss the social, work system and economic factors of the fishermen. Then, it will also analyze in relation to meeting the needs of fishermen as an indicator of fishermen's welfare.

\section{Material and Methods}

\subsection{Material}

The data of this research are primary data taken directly from 115 fishermen in Ambulu Village, Losari District, Cirebon Regency, West Java as of November 2020. The factors studied consisted of age, education level, marital status, and number of family members. The social factors are fishing system, time to go to sea, and duration of 
fishing; for work system factors, credit/loan ownership, fishing gear ownership, and fulfilment of needs for economic factors.

Data processing is presented as a percentage of each factor using Microsoft Office Excel 2010 software. The data analyses regarding of each factor in relation to the economy of the fisheries community. Furthermore, in formulating the recommendation of the factors that exist for economic development fisheries community in Indonesia.

\subsection{Fishermen and their Characteristics}

Fishermen are people whose livelihoods are catching fish (Poerwadarminto , 1993) or it can also be interpreted that they are providers of fishing properties and/or fishermen (Mulyadi , 2005). By law in Indonesia, fishermen are people who actively work in catching fish or other marine life. In their life, fishermen are inseparable from social and economic elements, and are closely related to fishing in the sea as the work of the fishermen themselves. These elements, in terms of believing, acting, or feeling, are characteristics of fishermen (Boere, 2008).

The characteristics of fishermen according to Rokhmawati (2016) are divided into five points of view, namely equipment ownership, business capital, fishing gear, labor and length of time at sea. In addition, other characteristics possessed by fishermen are age and level of education (Budi, 2015) which are closely attached to the social life of fishermen. Then, there are also fishermen characteristics in terms of the number of dependents in the family, income and expenses in the context of meeting the needs of the fishermen themselves (Yunita, 2018).

\section{Results and Discussion}

From the data on 115 fishermen responses in Ambulu Village, Losari District, Cirebon Regency, West Java, the following results were obtained related to their economy.

\subsection{Results}

First of all, it will be discussed starting from social factors which include age, education level, marital status, and number of family members. The age distribution of fishermen has descriptive statistics as in Table $\mathbf{1}$ and the distribution of the proportion of age productivity of fishermen is shown in Figure 1. The productive age at work ranges from 17 years to 40 years.

Table 1: Age Descriptive Statistics of Fishermen

\begin{tabular}{|c|c|c|c|}
\hline Minimum Age & Maximum age & Average & Deviation \\
\hline 25 years & 80 years & 43.04 years & 10.8 years \\
\hline
\end{tabular}

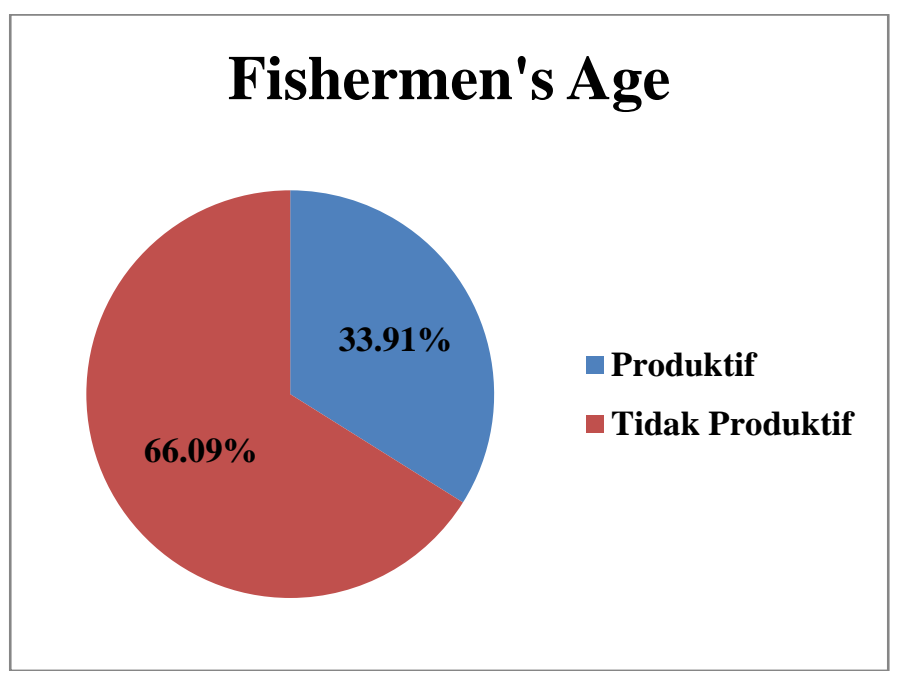

Figure 1: Proportion of Age Productivity of Fishermen

From these results, it can be concluded that the majority of the fishermen in the village Ambulu are at the nonproductive age which is over 40 years old and the average age has also been a little over the productive limit age. Furthermore, in terms of education level, fishermen in Ambulu Village have the proportion of final education as shown in Figure 2 below 


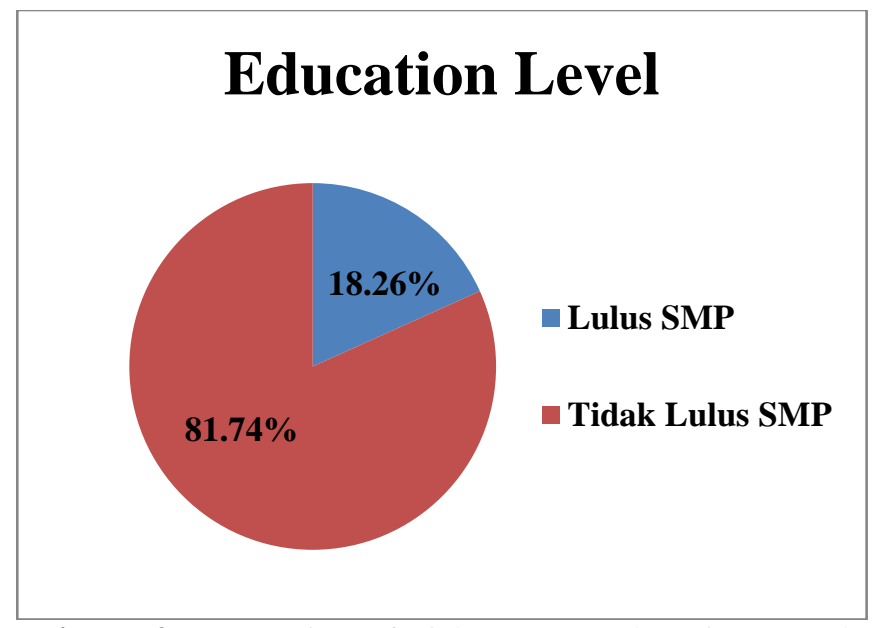

Figure 2: Proportion of Fishermen's Education Level

The results of the education level of fishermen in Ambulu Village show that most of them do not graduate from junior high school (SMP) level, so it can be concluded that fishermen have not received good educational standards to improve their welfare. Then, in terms of having a family, fishermen in Ambulu Village have a proportion as in Figure 3 below.

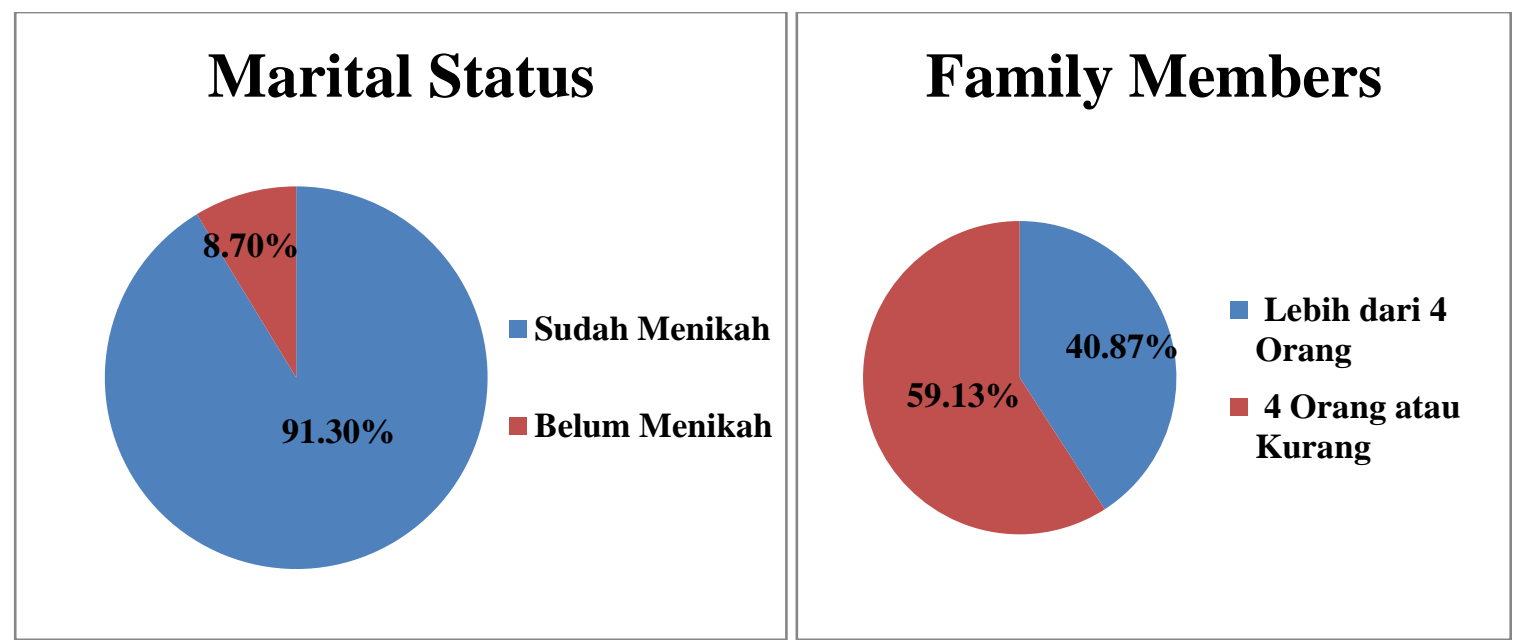

Figure 3: Proportion of Fishermen family

From these results, it can be said that almost all fishermen are married outside of the considerations of being able to meet the needs of their families. In addition, the majority of fishermen have family members of 4 people or less, so it is still possible to support the fulfilment of their needs, especially if the family income is small.

After talking about social factors, we will discuss factors regarding the working system of the fishermen. The working system of fishermen includes the system at sea, time to go to sea, and duration of the sea. The proportion of the fishing system of fishermen is shown in Figure 4, while the proportion of time and duration of fishing is shown in Figure 5.

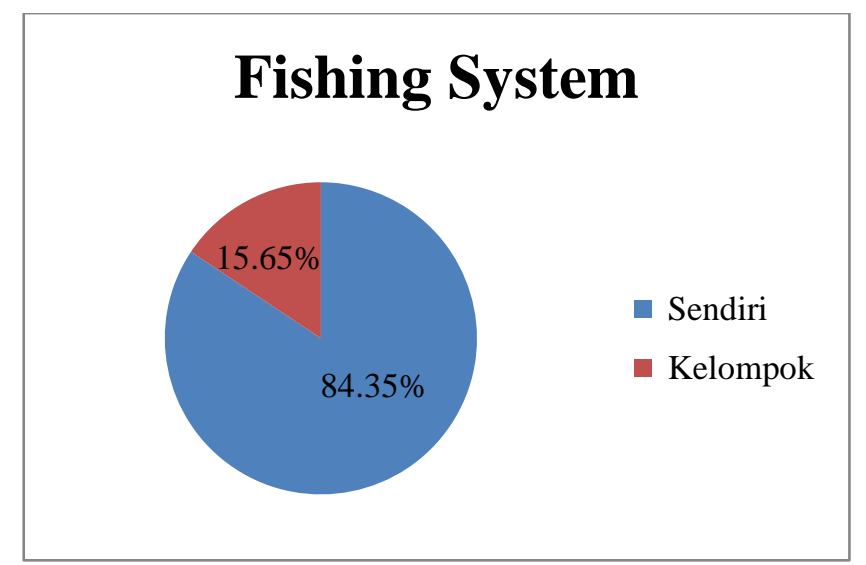

Figure 4: Proportionof Fishermen Fishing System 


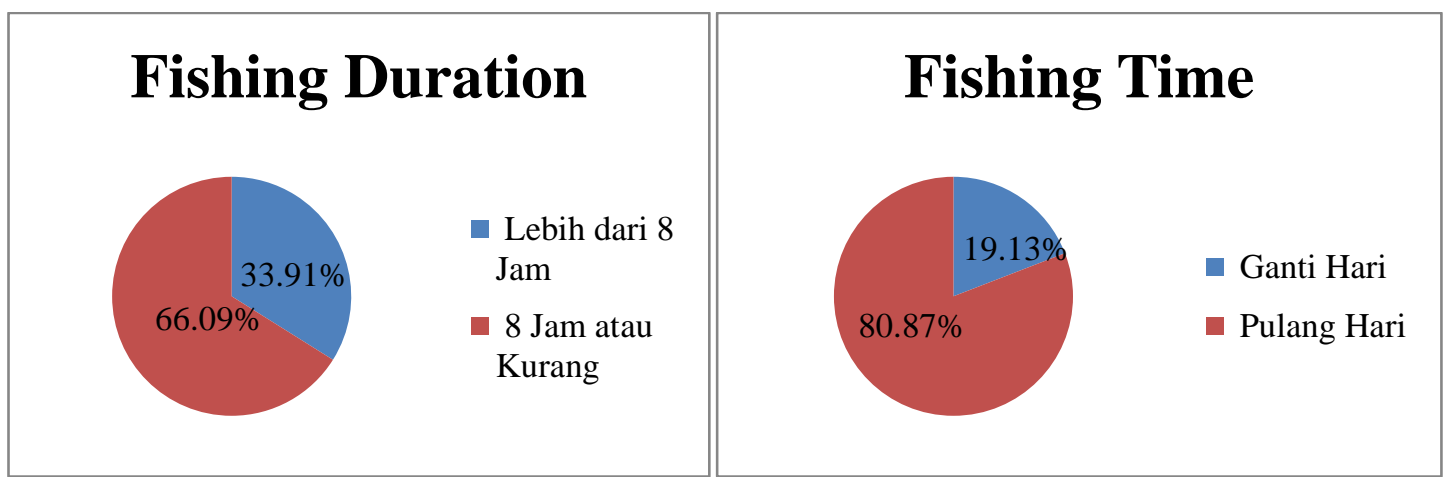

Figure 5: Proportion of Time and Duration of Fishing

From these results, it can be said that most of the fishermen still go to sea separately, so the catch will tend to be less without the need to share the catches. In addition, most fishermen go to and from the sea on the same day with a duration that is mostly not more than 8 hours in one day. Basically, fishermen's business, seen from the time and duration of fishing, is still possible to increase if there is a lack of income to meet the needs.

Finally, we will discuss the economic factors of the fishermen themselves. Economic factors include credit/loan, fishing gear ownership, and fulfilment of needs. The proportion of credit/loan and fishing gear from fishermen is shown in Figure 6, and the proportion of fulfilling the needs of fishermen's families is shown in Figure 7.

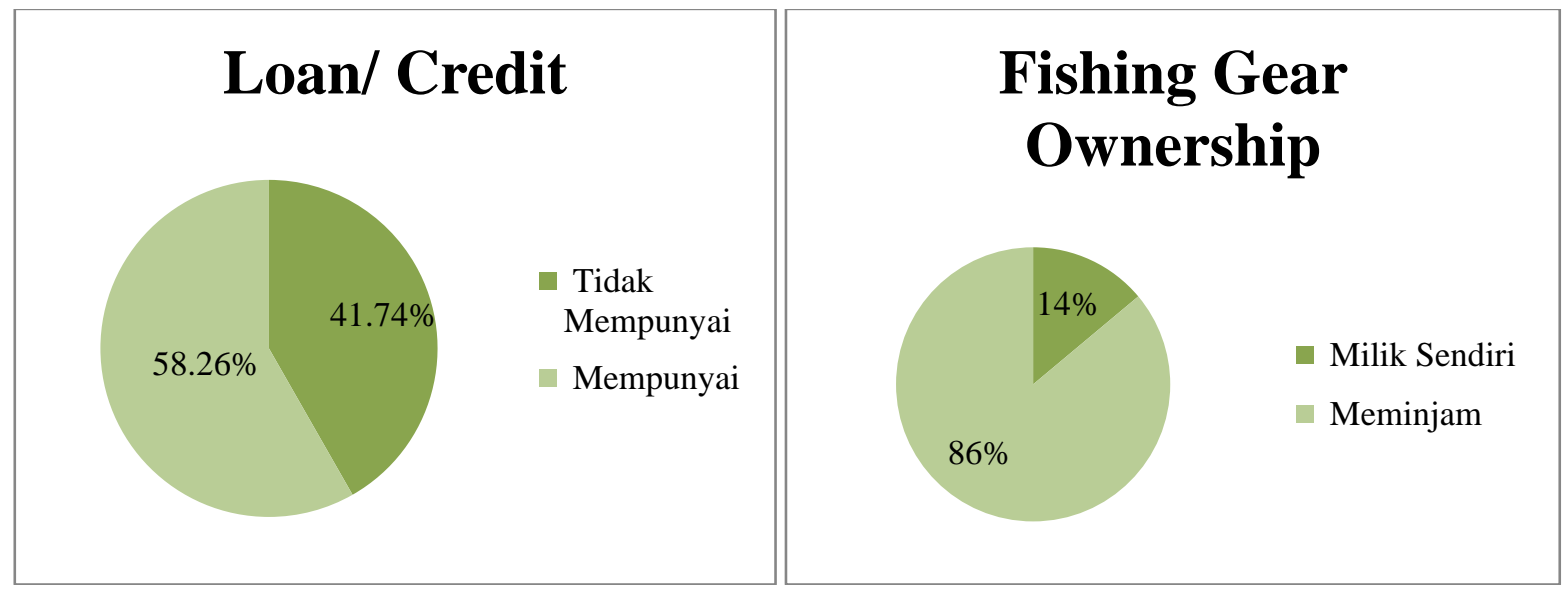

Figure 6: Proportionof Loan/ Credit and Fishing Gear Ownership

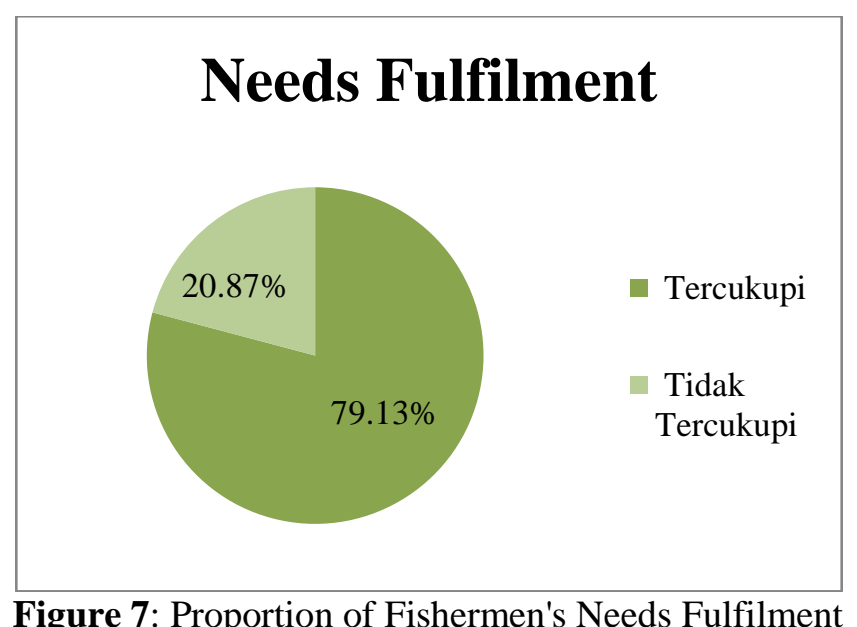

From these results, it can be concluded that indeed the majority of fishermen have credit/loans to meet their daily needs or business capital. In addition, most fishermen do not have their own fishing gear but borrow it from other people which results in sharing of profits or income. Then, in terms of fulfilling needs, it can be said that the majority of fishermen are already able to meet the daily needs of their families; however, seeing the factors of credit/loans 
create possibility the existing needs not to be met at a time because they have to pay, or maybe fishermen will constantly be entangled in credit/loan.

\subsection{Analysis}

From the results of the factors that can affect the fishermen's economy, a discussion of each factor will be conducted. First, the age factor, which, as seen and already explained, is that the age of fishermen is no longer productive. This makes it possible from a physical point of view that they are no longer fit to work, especially when they are past the age of 40 . The solution to this problem is to do regeneration from the fishermen themselves or a fishing system that is no longer individual but in groups between those who are no longer productive and those who are still productive in age so that they can get maximum results.

In terms of education level, fishermen are still far from smart. This is certainly not in line with one of the country's visions to educate the citizens. Many fishermen do not have basic knowledge that is useful in life thus it directly or indirectly affects the difficulty of increasing the welfare of the fishermen themselves. Most fishermen families, because they do not have enough provisions, think simply that in the future they can continue their life as fishermen like their predecessors and will not change their level of welfare.

The fishermen's own family factor, it is better if fishermen are not too quick to decide to get married, especially if the economic conditions for fulfilling their needs are still not in good condition. In addition, the number of existing family members must also be maintained so that the needs of fishermen's families are not excessive. The solution to the quantity of fishing families is that they can participate in the Family Planning program and other family assistance or programs from the government.

The duration and time spent at sea for fishermen itself have shown an efficient proportion, meaning that the duration and time spent at sea is still possible to increase if additional income is needed. However, from the fishing system, it seems that it is necessary to build a thought for the existence of a system of fishing in groups because it can help the quality and quantity of income. Then it is possible to regenerate for a better age as fishermen and indirectly the level of safety is more guaranteed because it is done together.

In fulfilling their daily needs, most of the fishermen are able to fulfil them well. However, the number of fishermen that cannot meet their daily needs is still quite high. Moreover, there are still many who have credit/loans and they do not have fishing equipment capital. In addition, the dynamic or erratic nature of income and expenditure can cause changes at any time in the conditions for fulfilling the needs of fishermen's families. Better conditions can be achieved if fishermen have advantages that can be used if a time is needed, no longer have credit/loans that can reduce the economic level of the fishermen themselves.

\section{Conclussion}

Improving fishermen in regeneration so they are at productive age and sufficient educational level. Therefore, they can get a standard/quality of life. Furthermore, the number of fisherman family members must be controlled so as not to require excessive fulfilment of needs. The working system of fishermen does not require much change, it is just that to get a more productive age, fishermen can go through a group fishing system. Meeting the needs of fishermen is still under control. However, seeing that there is still a rise in the inability of fishermen to meet their daily needs and the large level of credit/loan, better financial management is still needed. In addition, efforts will be made other than fishing from fishermen to improve their economic condition, which can indirectly improve the welfare of fishermen families.

\section{Acknowledgments}

Acknowledgments are conveyed to the Director of General of Higher Education of the Republic of Indonesia, and Chancellor, Director of the Directorate of Research, Community Engagement, and Innovation, and the Dean of the Faculty of Mathematics and Natural Sciences, Universitas Padjadjaran, who have provided the Community Service Scheme Grant with Contract Number:1397/UN6.3.1/PM/2020.

\section{References}

Agrawal, S., \& B. Mazumder. (2013). Cognitive Abilities and Household Financial Decision Making. American Economic Journal: Applied Economics, 5(1), 193-207.

Anwar, Z. \& Wahyuni. (2019). Miskin Di Laut Yang Kaya: Nelayan Indonesia dan Kemiskinan. Sosioreligius, I(4), 51-60.

Boere. (2008). Berbagai Teori Karakteristik Manusia. Jakarta: Pustaka. 
Budi, S. (2015). Identifikasi Karakteristik Nelayan Perikanan Tangkap dan Persepsinya Terhadap Peran Lembaga Hukum Adat Laot di Kota Lhokseumawe. Acta Aquatica. 2(2), 79-82.

Firdaus, M., \& Witomo, C. M. (2014). Analisis Tingkat Kesejahteraan dan Ketimpangan Pendapatan Rumah Tangga Nelayan Pelagis Besar di Sendang Biru, Kabupaten Malang, Jawa Timur. Jurnal Sosial Ekonomi Kelautan dan Perikanan, 9(2), 155168.

Mulyadi. (2005). EkonomiKelautan. Jakarta: PT. Rajagarfindo Persada.

Poerwadarminto, W. J. S. (1993). Kamus Umum Bahasa Indonesia. Cetakan XIII. 674. Jakarta: Balai Pustaka.

Prihandoko, S., et al. (2012). Kondisi Sosial Ekonomi Nelayan Artisanal di Pantai Utara Provinsi Jawa Barat. Jurnal Penyuluhan, $8(1)$.

Rokhmawati, A. (2016). Karakteristik dan Pendapatan Nelayan di Desa Jetis Kecamatan Nusawungu Kabupaten Cilacap. Bachelor Thesis, Universitas Muhammdaiyah Purwokerto (UMP).

Yunita, E., et al. (2018). Kondisi Sosial Ekonomi Masyarakat Nelayan Di Pantai Labuhan Jukung Krui Pasca Terbentuknya Kabupaten Pesisir Barat. Jurnal Studi Sosial, 6(1), 2018. 